\title{
Obtaining Martensitic Structures during Thixoforming of Hypoeutectic Gray Cast Iron
}

\author{
Lucas Bertolino Ragazzo, ${ }^{1}$ Davi Munhoz Benati, ${ }^{1}$ \\ Rodolfo Lopez Nadal, ${ }^{2}$ and Eugênio José Zoqui ${ }^{1}$ \\ ${ }^{1}$ Department of Materials and Manufacturing Engineering, Faculty of Mechanical Engineering, University of Campinas, \\ 13083-860 Campinas, Brazil \\ ${ }^{2}$ Department of Materials and Manufacturing, Faculty of Mechanical Engineering, University of Oriente, \\ 90400 Santiago de Cuba, Cuba
}

Correspondence should be addressed to Eugênio José Zoqui; zoqui@fem.unicamp.br

Received 1 June 2015; Revised 17 July 2015; Accepted 26 July 2015

Academic Editor: Olanrewaju Ojo

Copyright (C) 2015 Lucas Bertolino Ragazzo et al. This is an open access article distributed under the Creative Commons Attribution License, which permits unrestricted use, distribution, and reproduction in any medium, provided the original work is properly cited.

\begin{abstract}
The control of parameters such as liquid fraction, holding time, and cooling rate during thixoforming can help control the final microstructure of the thixoformed part, thus improving its mechanical properties. This study intended to investigate conditions required to obtain martensite in hypoeutectic gray cast iron at $3.1 \% \mathrm{CE}$ (carbon equivalent) deformed in the semisolid state. Samples heated up to 1130,1135 , and $1145^{\circ} \mathrm{C}$ (liquid fractions of 10,30 , and $45 \%$ ) were compressed into platens without any holding time (0 s). If a sample presented a martensitic structure for $0 \mathrm{~s}$ holding time, new samples were retested at the same temperature for 30, 60, and $90 \mathrm{~s}$ holding times. The die casting process was simulated by allowing the platens to become locked after hot compression. Samples that cooled in the locked platens were submitted to higher cooling rates than samples that cooled with the platens open and presented martensite instead of the conventional ferrite and pearlite. Thus, the factor that had the greatest influence on the formation of martensite was the cooling rate rather than stress. The thixoforming process presented good morphological stability, which is highly desirable for industrial applications.
\end{abstract}

\section{Introduction}

Thixoforming involves heating a material until it reaches the semisolid state followed by forming. The mechanical properties of the thixoformed product are determined by the final microstructure of the material used. Controlling some of the process parameters, such as liquid fraction (by adjusting the temperature in the semisolid state region), holding time (the time to ensure a homogeneous structure in the semisolid state), deformation, and cooling rate, can help control the final microstructure and promote martensitic transformation, thus improving the mechanical properties of the thixoformed parts $[1,2]$.

Steel and cast iron have been widely researched as potential raw materials for semisolid processing and have been shown to have a wide range of beneficial properties, such as good fluidity and stability in the semisolid state [37]. Moreover, cast irons, which are low cost alloys, have a great variety of microstructures and, therefore, controllable mechanical properties, making them particularly suitable for applications where wear resistance is required [8]. Some cast irons, including hypoeutectic gray cast iron, have been successfully used as raw material for semisolid processing [9-12].

Martensitic transformation is a diffusionless shear transformation and involves no change in composition. In steels it is of particular importance, as it can confer an outstanding combination of strength and toughness. Many materials other than steel, such as cast irons and other $\mathrm{Fe}-\mathrm{C}$ based alloys, nonferrous metals, pure metals, ceramics, minerals, inorganic compounds, solidified gases, and polymers, are now known to exhibit the same type of solid-state phase transformation, and in many the mechanism involved in the transformation is fully understood [13].

This paper seeks to investigate the conditions needed to produce a partial or full martensitic structure instead 

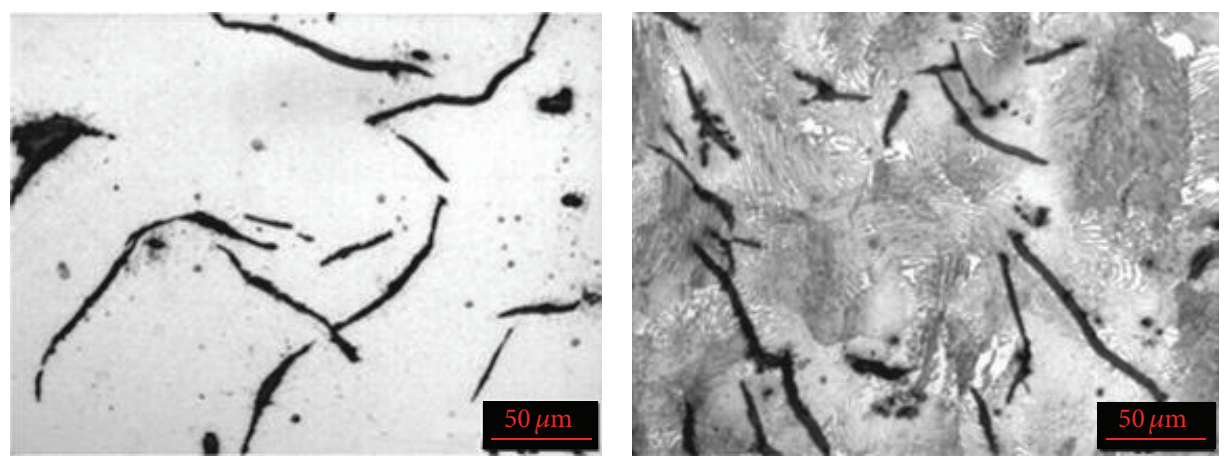

FIGURE 1: As-cast structure of the hypoeutectic gray cast iron without and with nital etching showing predominantly type A flake graphite in a ferritic-pearlitic matrix [12].

TABLE 1: Chemical composition of hypoeutectic gray cast iron (in wt $\%)$.

\begin{tabular}{lcccccr}
\hline $\mathrm{C}$ & $\mathrm{Si}$ & $\mathrm{Mn}$ & $\mathrm{P}$ & $\mathrm{S}$ & Others $^{\mathrm{a}}$ & $\mathrm{CE}^{\mathrm{b}}$ \\
\hline 2.61 & 1.54 & 0.32 & 0.05 & 0.008 & 0.024 & 3.1 \\
\hline
\end{tabular}

${ }^{a}$ Residual elements such as $\mathrm{Ni}, \mathrm{Cr}, \mathrm{Cu}$, and $\mathrm{Mo}$.

${ }^{b} \mathrm{CE}=w t \% \mathrm{C}+1 / 3 \mathrm{wt} \% \mathrm{Si}$.

of a conventional graphite-ferrite or graphite-ferrite/pearlite matrix in hypoeutectic gray cast iron severely deformed in the semisolid state in hot-compression tests. Three thixoformability parameters (liquid fraction, cooling rate, and holding time) were controlled to identify the conditions and parameters that can be adjusted to control the final microstructure of the thixoformed material. This alloy, proposed as raw material for semisolid processing, was designed in order to achieve a chemical composition that would provide around $50 \%$ of liquid after the melting of the eutectic phase at the semisolid state. A composition of $2.6 \mathrm{wt} \% \mathrm{C}$ and $1.5 \mathrm{wt} \% \mathrm{Si}$ or approximately $3.1 \% \mathrm{CE}$ (carbon equivalent) was achieved according to what is described in previous work [12].

\section{Experimental Procedure}

$1000 \mathrm{~kg}$ of hypoeutectic gray cast iron was produced by melting $200 \mathrm{~kg}$ of pig iron, $650 \mathrm{~kg}$ of GG25 gray cast iron scrap, and $150 \mathrm{~kg}$ of AISI1020 steel scrap as raw materials. The molten metal was homogenized at $1480^{\circ} \mathrm{C}$ in an $8 \mathrm{kHz}$ $350 \mathrm{~kW}$ induction furnace. $3.5 \mathrm{~kg}$ of grain refiner based on aluminium/calcium silicate was also used. The alloy was poured into $35 \mathrm{~mm}$ diameter $250 \mathrm{~mm}$ high sand cast molds at a pouring temperature between 1415 and $1380^{\circ} \mathrm{C}$ (about $100^{\circ} \mathrm{C}$ above the liquidus temperature) and the cooling time to demolding was two hours. The chemical composition is shown in Table 1. In the as-cast condition this alloy consists of predominantly type A flake graphite in a ferritic-pearlitic matrix as shown in Figure 1 with around $7.5 \%$ of graphite, $5.3 \%$ of ferrite, and $87.2 \%$ of pearlite [12].

Before the sample reaches the target temperature for the hot-compression test, melting begins in the eutectic phase (corresponding to a mixture of graphite and austenite, or $\gamma$-Fe, which is usually referred to as the secondary phase

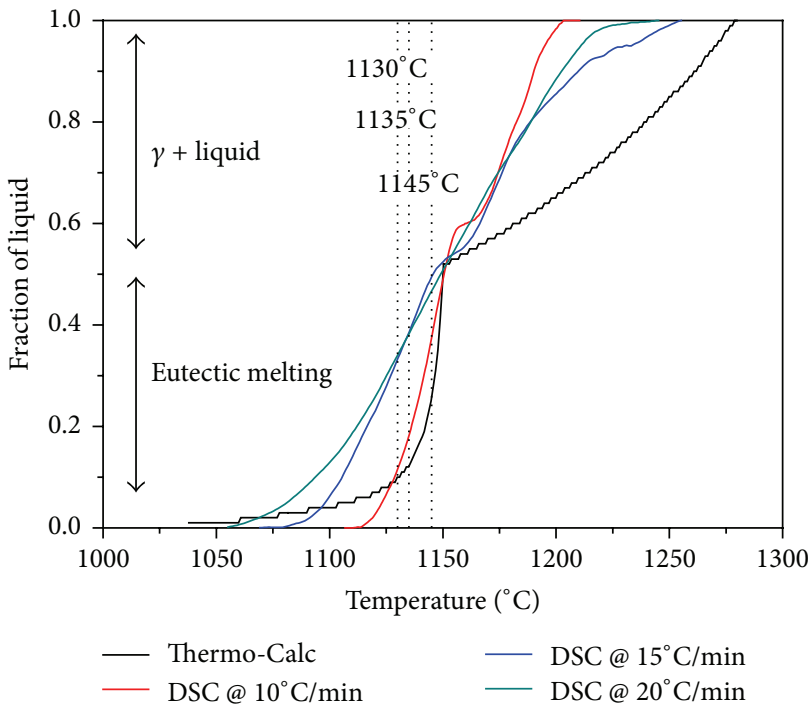

FIGURE 2: Expected liquid fraction for hypoeutectic gray cast iron showing the temperature range corresponding to unstable eutectic melting as well as the ideal range for thixoforming based on simulation using Thermo-Calc and DSC [12].

in thixoforming operations). It continues in the austenitic phase (known as the primary phase), which is consumed as the temperature increases. Figure 2 shows the expected liquid fraction as a function of process temperature for the Fe-2.6 wt\% C- $1.5 \mathrm{wt} \% \mathrm{Si}$ alloy produced. The graph was plotted using Thermo-Calc simulation software and differential scanning calorimetry (DSC) at heating rates of 10,15 , and $20^{\circ} \mathrm{C} / \mathrm{min}$ in a Netzsch STA $409 \mathrm{C}$ thermogravimetric analyzer. During heating, $\mathrm{Fe}_{3} \mathrm{C}$ and ferrite transform into austenite at about $785^{\circ} \mathrm{C}$ (austenitizing temperature), and at about $1150^{\circ} \mathrm{C}$ the graphite dissolves completely, when the alloy consists of $50 \%$ solid (austenite) and 50\% liquid with a eutectic composition, that is, eutectic melting. Hence, as shown in Figure 2, alloys heated to 1130,1135 , and $1145^{\circ} \mathrm{C}$ lie in a narrow range between two zones containing austenite $(\gamma)$, graphite $(G)$, a small amount of MnS (not shown), and liquid. This accounts for the different liquid fractions at these three temperatures (10,30, and $45 \%$, resp.) (average values for 


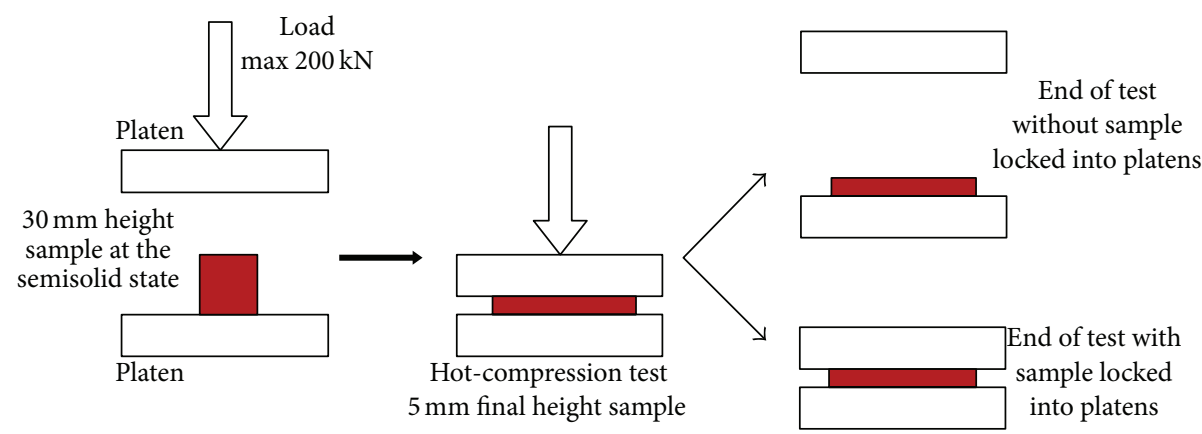

FIGURE 3: Schematic illustration of the hot-compression test showing how the platens become locked for samples with a lower liquid fraction.

the different techniques and cooling rates used). Note that the chosen temperatures are within the first temperature range, where unstable eutectic melting occurs. These temperatures were chosen together with a high solid content because one of the first aims was to evaluate the possibility of producing stress-induced martensitic transformation in thixoforming operations. However, regular thixoforming operations with the material used here are normally carried out at higher temperatures, that is, within the $\gamma /$ liquid range [12].

Samples $30 \mathrm{~mm}$ high and $30 \mathrm{~mm}$ in diameter were first heated up to the semisolid state in an $8 \mathrm{kHz} 25 \mathrm{~kW}$ induction furnace. They were then severely deformed to a final height of $5 \mathrm{~mm}$ without any lateral constraint between two AISI $\mathrm{H} 13$ steel platens in an instrumented eccentric press with a $200 \mathrm{kN}$ load capacity. The total test time was less than $0.5 \mathrm{~s}$. Experiments were replicated three times for each condition analyzed.

Compressed samples were sectioned in the transversal direction, polished up to $0.3 \mu \mathrm{m}$, and etched with $1 \%$ nital (nitric acid and ethyl alcohol) for microstructure analysis by light microscopy (LM) and scanning electron microscopy (SEM) to determine grain size (based on interdendritic arm spacing, or IAS), graphite content, graphite flake length, and predominant graphite type. The IAS was measured according to ASTM E112:1996 Standard. Graphite content and graphite flake length were measured using ImageJ software. Eight micrographs were taken from different regions of each one of the three replicas. Pictures were taken of both the edge and the center of each sample along the $5 \mathrm{~mm}$ of height. The IAS was counted in three fields on each micrograph. Graphite content and graphite flake length were evaluated in each one of the eight micrographs of each sample. Vickers microhardness tests were performed with a $200 \mathrm{~g}$ load for $10 \mathrm{~s}$. Six measurements were taken from different regions of each one of the three replicas along the height from the edge to the center of the sample.

If a sample tested with a $0 \mathrm{~s}$ holding time was found to contain martensite, samples were retested at the same temperature for holding times of 30,60 , and $90 \mathrm{~s}$ to explore the relationship between martensitic transformation and rheological behavior during semisolid forming. If a sample tested with $0 \mathrm{~s}$ holding time (corresponding to the highest stress during compression) did not contain martensite, then samples produced with longer holding times would definitely
TABLE 2: Sequence of tests performed.

\begin{tabular}{llccc}
\hline $\begin{array}{l}\text { Temperature } \\
\left({ }^{\circ} \mathrm{C}\right)\end{array}$ & $\begin{array}{l}\text { Liquid } \\
\text { fraction } \\
(\%)\end{array}$ & $\begin{array}{c}\text { Holding } \\
\text { time } \\
(\mathrm{s})\end{array}$ & $\begin{array}{c}\text { Cooled } \\
\text { sample stuck } \\
\text { to platen? }\end{array}$ & $\begin{array}{c}\text { Martensite } \\
\text { formed? }\end{array}$ \\
\hline 1145 & 45 & 0 & No & No \\
\hline 1135 & 30 & 0 & No & No \\
\hline & & 0 & Yes & Yes \\
1130 & 10 & 30 & Yes & Yes \\
& & 60 & Yes & Yes \\
& 90 & No & No \\
\hline
\end{tabular}

not contain this phase as stress decreases with increased holding time for semisolid compression tests because of the better morphological conditions at longer holding times [12]. The cooling rate can also be investigated during hotcompression tests by allowing the platens to become locked when the samples are forming. This procedure simulates conventional thixoforming in injection die casting machines, where final solidification occurs under constant stress inside the closed dies. This situation is illustrated in Figure 3.

When the platens became locked, the samples remained in contact with both platens and therefore cooled at higher rates than samples that cooled with the platens open (when the samples were in contact with the steel platen and the air). The higher cooling rates in the former case favor the formation of martensite.

\section{Results and Discussion}

The sequence of tests performed is shown in Table 2. As described in Experimental Procedure, when samples subjected to a holding time of $0 \mathrm{~s}$ were found to contain martensite, additional samples were tested at the same temperature for holding times of 30,60, and $90 \mathrm{~s}$. The objective was to identify the conditions that simulated die casting, that is, the conditions under which the samples became stuck between the platens. For $0 \mathrm{~s}$ holding time the only target temperature for which martensite formed was $1130^{\circ} \mathrm{C}$. Samples were therefore tested for holding times of 30,60 , and $90 \mathrm{~s}$ with this temperature. Only the first two times resulted in the formation of martensite. 

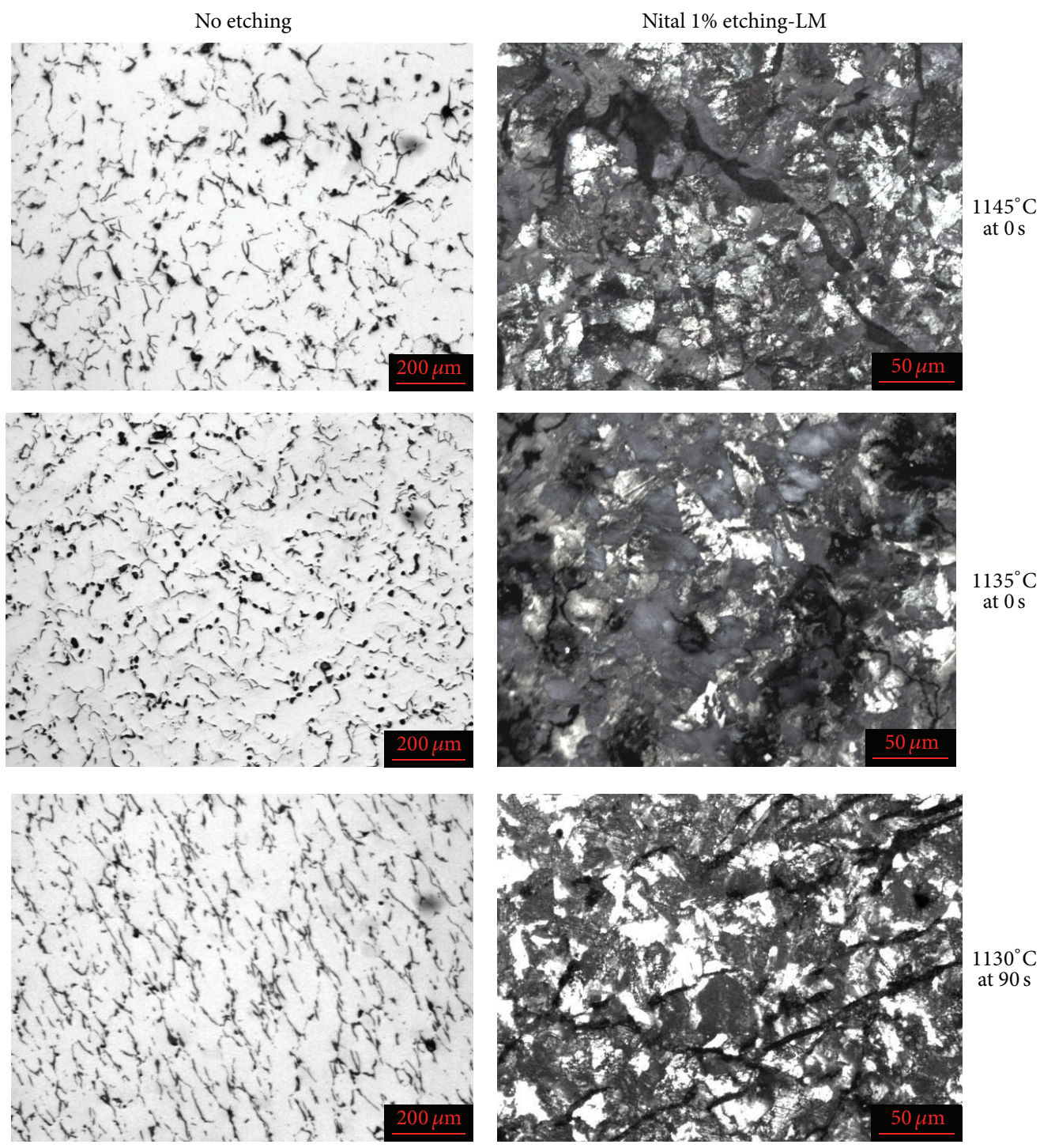

FIGURE 4: Hypoeutectic gray cast iron tested with target temperatures of 1145,1135 , and $1130^{\circ} \mathrm{C}$ and 90 s holding time, showing predominantly type E flake graphite and a ferrite-pearlite matrix.

Table 2 shows that for target temperatures of 1145,1135 , and $1130^{\circ} \mathrm{C}$ and $90 \mathrm{~s}$ holding time (i.e., tests in which the platens did not become locked) there was no martensitic formation. In contrast, for a target temperature of $1130^{\circ} \mathrm{C}$ and 0,30 , and $60 \mathrm{~s}$ holding times (i.e., tests in which the platens did become locked) there was partial or full martensitic transformation. The former conditions imposed lower cooling rates on the samples, preventing martensite forming and leading instead to a conventional ferrite-pearlite microstructure. Despite the low liquid fraction for a temperature of $1130^{\circ} \mathrm{C}$ and holding time of $90 \mathrm{~s}$ (only $10 \%$ compared with 30 or $45 \%$ for tests at 1135 or $1145^{\circ} \mathrm{C}$ ), this holding time, like the tests at 1135 and $1145^{\circ} \mathrm{C}$, did not result in martensite formation.

Figure 4 shows the microstructures of the samples used in tests that did not cause the platens to lock, that is, target temperature and holding time combinations of $1145^{\circ} \mathrm{C} / 0 \mathrm{~s}$, $1135^{\circ} \mathrm{C} / 0 \mathrm{~s}$, and $1130^{\circ} \mathrm{C} / 90 \mathrm{~s}$, for which there was no martensite formation during semisolid forming. All the pictures were taken with LM and show predominantly type E flake graphite in a ferrite-pearlite matrix.

Despite the differences in liquid fraction for the three target temperatures $\left(45,30\right.$, and $10 \%$ for 1145,1135 , and $1130^{\circ} \mathrm{C}$, resp.), there was no significant change in the morphology of the graphite and matrix microstructure between the three conditions of Figure 4 because the same cooling rates were achieved. The microstructure can be accounted for by the temperature and liquid fraction. High temperatures increase the liquid fraction, allowing a high degree of deformation, and long holding times allow the liquid phase to penetrate and dissolve the solid particles where they are in contact with each other, thereby also allowing a high degree of deformation.

Figure 5 shows the microstructures obtained with a target temperature of $1130^{\circ} \mathrm{C}$ and 0,30 , and $60 \mathrm{~s}$ holding times, that 

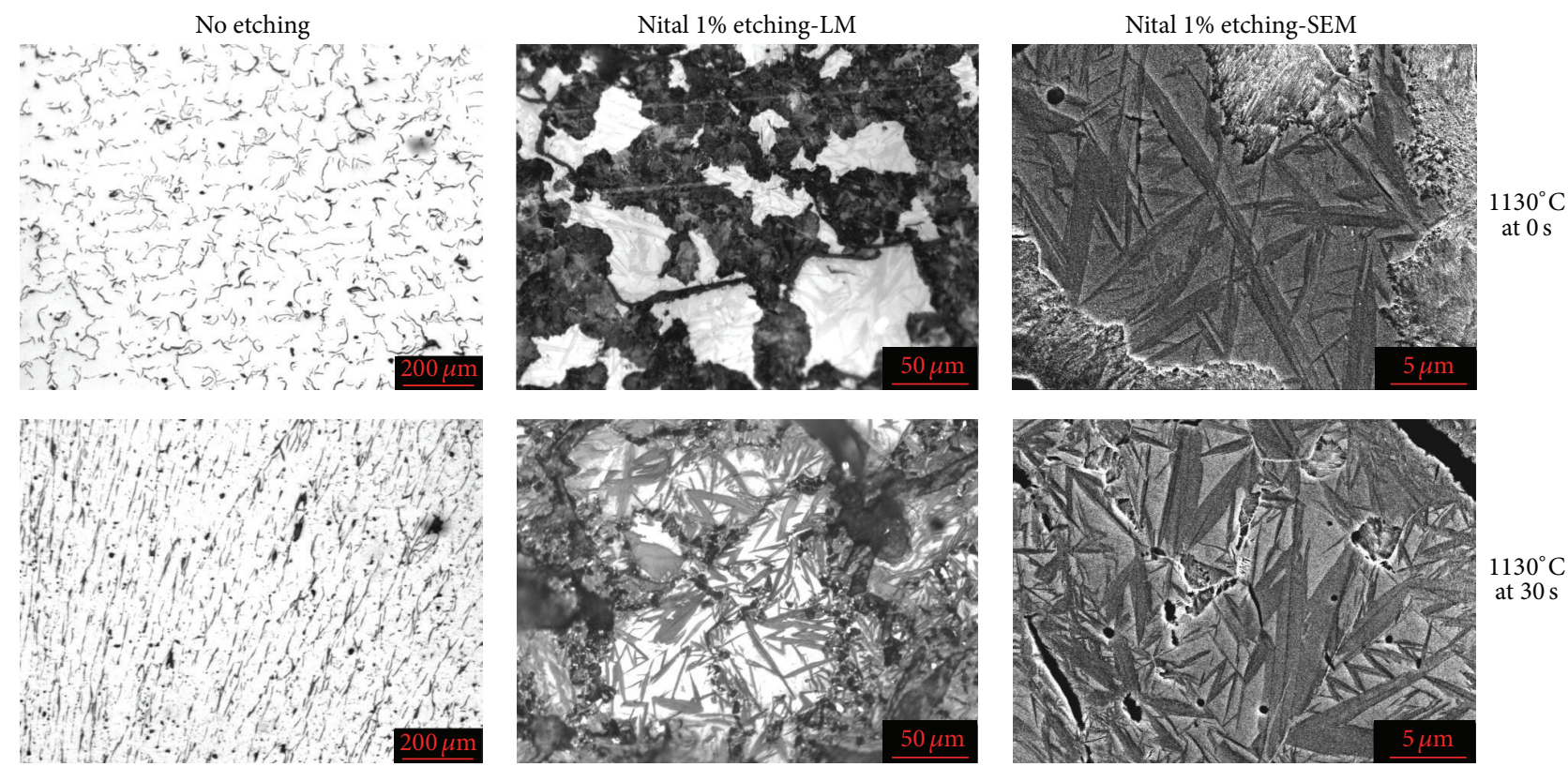

$1130^{\circ} \mathrm{C}$ at $30 \mathrm{~s}$
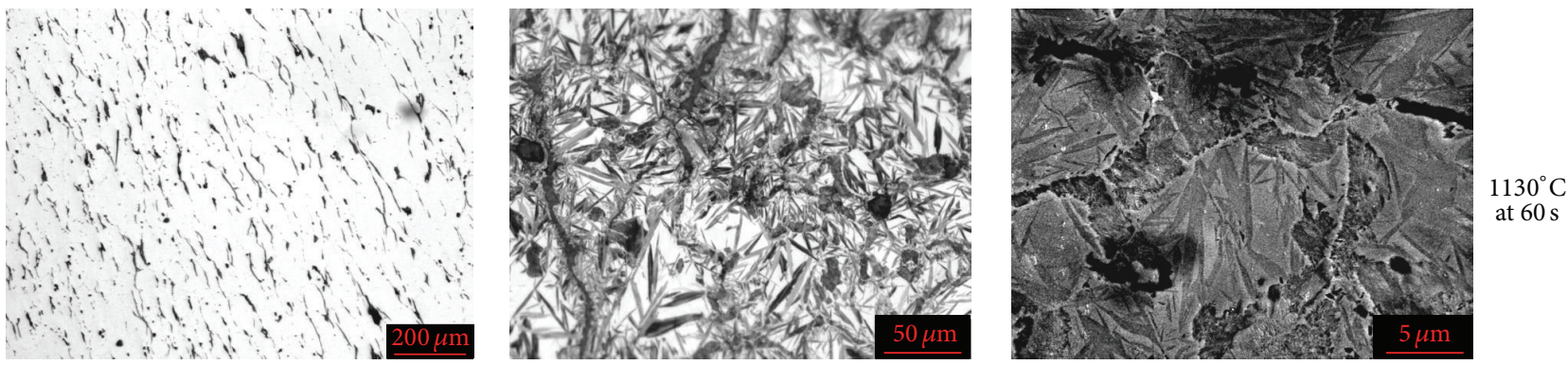

Figure 5: Hypoeutectic gray cast iron tested with a target temperature of $1130^{\circ} \mathrm{C}$ and 0,30 , and $60 \mathrm{~s}$ holding times, showing predominantly type E flake graphite and martensite in a ferrite-pearlite matrix.

is, tests in which martensite formed during semisolid forming. Samples tested at $1130^{\circ} \mathrm{C}$ and $0 \mathrm{~s}$ holding time exhibited partial martensitic transformation and martensite colonies surrounded by a ferrite-pearlite matrix, while samples tested at $1130^{\circ} \mathrm{C}$ and 30 and 60 s holding times exhibited full martensitic transformation. In fact, to obtain a full martensitic structure a short holding time is required, probably within the $30 / 60$ s interval, because a minimum time at the semisolid temperature range is required to homogenize the temperature throughout the sample.

The change from the type A flake graphite in the original raw material to the type E flake graphite in the semisolid compressed samples is explained by the faster cooling rate. When the raw material cools slowly, the graphite can spread around the edges of the grain. In contrast, when cooling takes place faster, whether the sample is stuck to the AISI H13 steel platen or not, there is very little time for diffusion to occur and type E graphite to form. Like type A flake graphite, type $\mathrm{E}$ is recommended for a wide range of applications, particularly those that require good wear resistance. Type $A$ is characterized by a uniform distribution and random orientation; it has intermediate-sized flakes and is typically the result of moderate cooling rates. Type E, in contrast, is characterized by interdendritic segregation, which has a preferred rather than a random orientation, and is typically the result of high cooling rates and has fine flakes, potentially increasing the need for machining and surface finishing [14].

It is also worth noting that the increase in stress during thixoforming was not enough by itself to produce martensite. Although more stress is required to form a sample with a lower liquid content, the hot-compressed sample with only $10 \%$ liquid content $\left(1130^{\circ} \mathrm{C}\right.$ at $\left.90 \mathrm{~s}\right)$ had the same morphological features as the samples with 30 or $45 \%$ liquid content (1135 or $\left.1145^{\circ} \mathrm{C}\right)$. This indicates that the main factor influencing martensitic transformation in this alloy in these specific situations was cooling rate rather than stress. To evaluate the structure of the samples quantitatively, the parameters graphite content, interdendritic arm spacing (IAS, which is equivalent to grain size), and graphite flake length were measured. The results can be seen in Table 3 .

As shown in Table 3, graphite content, IAS, and graphite flake length were statistically equivalent for all the samples under all the conditions evaluated. Achieving morphological stability in the semisolid state is, from an industrial perspective, the main goal of this type of processing and the main characteristic required for alloys used for this purpose. 
TABLE 3: Quantitative metallographic analysis of alloys (95\% confidence interval).

\begin{tabular}{lcccc}
\hline Condition & Predominant type of graphite & Graphite $(\%)$ & IAS $(\mu \mathrm{m})$ & Graphite flake length $(\mu \mathrm{m})$ \\
\hline As-cast & A & $7.5 \pm 0.8$ & $59.1 \pm 43.8$ & $57.5 \pm 38.9$ \\
$1145^{\circ} \mathrm{C}$ & $\mathrm{E}$ & $8.6 \pm 0.7$ & $57.8 \pm 19.7$ & $33.1 \pm 9.6$ \\
$1135^{\circ} \mathrm{C}$ & $\mathrm{E}$ & $8.8 \pm 1.1$ & $58.1 \pm 22.5$ & $32.5 \pm 6.9$ \\
$1300^{\circ} \mathrm{C}-0 \mathrm{~s}$ & $\mathrm{E}$ & $9.5 \pm 0.8$ & $45.2 \pm 15.4$ & $25.2 \pm 8.6$ \\
$1300^{\circ} \mathrm{C}-30 \mathrm{~s}$ & $\mathrm{E}$ & $10.1 \pm 0.7$ & $43.9 \pm 16.1$ & $22.9 \pm 9.3$ \\
$1300^{\circ} \mathrm{C}-60 \mathrm{~s}$ & $\mathrm{E}$ & $9.8 \pm 1.4$ & $42.9 \pm 16.6$ & $25.3 \pm 6.8$ \\
$1300^{\circ} \mathrm{C}-90 \mathrm{~s}$ & $\mathrm{E}$ & $10.3 \pm 1.6$ & $53.1 \pm 24.1$ & $31.3 \pm 8.5$ \\
\hline
\end{tabular}

TABLE 4: Vickers microhardness for alloys (95\% confidence interval).

\begin{tabular}{lcc}
\hline Condition & Predominant phase & Vickers microhardness (HV) \\
\hline $1145^{\circ} \mathrm{C}$ & Ferrite/pearlite & $331.3 \pm 31.6$ \\
$1135^{\circ} \mathrm{C}$ & & $325.1 \pm 36.7$ \\
\hline \multirow{2}{*}{$1130^{\circ} \mathrm{C}-0 \mathrm{~s}$} & Ferrite/pearlite & $379.5 \pm 39.9$ \\
& Martensite colonies & $577.8 \pm 34.6$ \\
\hline $1130^{\circ} \mathrm{C}-30 \mathrm{~s}$ & Martensite & $593.6 \pm 41.9$ \\
$1130^{\circ} \mathrm{C}-60 \mathrm{~s}$ & Martensite & $555.3 \pm 39.3$ \\
$1130^{\circ} \mathrm{C}-90 \mathrm{~s}$ & Ferrite/pearlite & $329.3 \pm 30.2$ \\
\hline
\end{tabular}

The results of the Vickers microhardness tests are shown in Table 4. For the ferrite-pearlite matrix, microhardness values were of the order of 325 to $377 \mathrm{HV}$. However, as a 95\% confidence interval was used, they are all statistically equivalent. Values for the martensitic matrix ranged from 555 to $593 \mathrm{HV}$ and were all also statistically equivalent. The latter values are $60 \%$ higher than those for the ferrite-pearlite samples, showing that martensite transformation occurred in samples that stuck to the platens during hot-compression tests. For samples heated to $1130^{\circ} \mathrm{C}$ and subjected to a holding time of $0 \mathrm{~s}$, the microhardness was measured in each phase (ferrite-pearlite and martensite) and was equal to the values for the same phases in samples subjected to the other conditions.

Although with a $95 \%$ confidence interval there is no statistically significant variation in the graphite content, IAS, and graphite flake length for the different target temperatures and holding times tested, the IAS and mean graphite flake length show a slight tendency to decrease in martensitic microstructures. In contrast, there is a statistically significant increase in Vickers microhardness in martensitic microstructures, due to this phase being much harder than ferrite and pearlite-so in this case, the IAS and graphite length are obviously not the main reason for increase in hardness.

Finally, in terms of an industrial context, thixoforming with the platens locked is equivalent to semisolid state closed die casting. The main parameter influencing martensite formation in this situation is the high cooling rate, which is a basic characteristic of injection processes. The experiment with the platens locked was intended to show that conventional die casting generates a partially or completely martensitic microstructure that is the result of thermal transformation rather than being stress-induced.
The final microstructure can therefore be controlled by controlling the cooling rate. When a structure with high mechanical strength and hardness is required and toughness is not an issue, the platens can be used at a conventional temperature of $200 / 250^{\circ} \mathrm{C}$ as in this study. If a microstructure with minimum fracture toughness is required, higher temperatures can be used to reduce the cooling rate and generate a pearlitic or pearlitic-ferritic microstructure or, depending on the cooling rate achieved, a mixture of martensite on the surface and pearlite and ferrite on the inside. Once the martensitic transformation generally occurs only at outer regions of the thixoformed part while inner regions preserve the conventional gray cast iron morphology (as presented in Figure 1) the thixoforming of gray cast iron could be suitable for manufacturing of parts that require a hard surface and relatively ductile core-like axles and gears. In this way the necessary microstructure can be achieved to ensure that the part has the required in-service performance, something that is very difficult or almost impossible to achieve in conventional casting.

\section{Conclusions}

This work aimed to identify the conditions required to produce martensitic structures in hypoeutectic gray cast iron at $3.1 \% \mathrm{CE}$ (carbon equivalent) with a high solid content severely deformed in the semisolid state in hot-compression tests. The main conclusions were as follows:

(i) A hot-compressed sample with only $10 \%$ liquid content $\left(1130^{\circ} \mathrm{C}\right.$ and $\left.90 \mathrm{~s}\right)$ had the same morphological features as hot-compressed samples with 30 or $45 \%$ liquid content $\left(1135\right.$ or $\left.1145^{\circ} \mathrm{C}\right)$ even though greater stress is required to form a sample with three to four times less liquid. This indicates that the main factor influencing martensitic transformation in this alloy under these specific conditions is the cooling rate rather than stress.

(ii) The key to the formation of martensite was the higher cooling rates for the samples that stuck to the platens. Vickers microhardness measurements showed that the hardness in martensitic regions was of the order of $60 \%$ greater than in ferrite-pearlite regions.

(iii) All samples presented predominantly type E flake graphite and graphite content, IAS, and graphite flake length were statistically equivalent for all the samples 
under all the conditions evaluated. From an industrial perspective, this morphological homogeneity during the semisolid state is the main goal of thixoforming and the main characteristic required in alloys used for this purpose.

\section{Conflict of Interests}

The authors declare that there is no conflict of interests regarding the publication of this paper.

\section{Acknowledgments}

The authors would like to thank Grant 2011/19997-0 from São Paulo Research Foundation (FAPESP), National Council for Scientific and Technological Development (CNPq), and Grant 095/2010 from Coordination for the Improvement of Higher Education Personnel (CAPES) for financial support and Faculty of Mechanical Engineering, State University of Campinas, for providing the necessary infrastructure.

\section{References}

[1] G. Hirt and R. Koop, Thixoforming-Semisolid Metal Processing, Wiley-VCH, Weinheim, Germany, 2009.

[2] D. H. Kirkwood, M. Suéry, P. Kapranos, H. V. Atkinson, and K. P. Young, Semisolid Processing of Alloys, Springer, Berlin, Germany, 2010.

[3] S. Sugiyama, J. Li, and J. Yanagimoto, "Semisolid extrusion of low-carbon steel," Materials Transactions, vol. 48, no. 4, pp. 807812, 2007.

[4] J. C. Pierret, A. Rassili, G. Vaneetveld, and J. Lecomte-Beckers, "Stability of steel thixoforming process," Transactions of Nonferrous Metals Society of China, vol. 20, no. 3, pp. s937-s942, 2010.

[5] A. Rassili and H. V. Atkinson, "A review on steel thixoforming," Transactions of Nonferrous Metals Society of China, vol. 20, supplement 3, pp. s1048-s1054, 2010.

[6] M. Tsuchiya, H. Ueno, and I. Takagi, "Research of semi solid casting of iron," JSAE Review, vol. 24, no. 2, pp. 205-214, 2003.

[7] H. Nomura, P. Qiu, M. Takita, and N. Poolthong, "Semi-solid processing of cast iron," Materials Transactions, vol. 42, no. 2, pp. 303-308, 2001.

[8] J. Cui, H. Zhang, L. Chen, H. Li, and W. Tong, "Microstructure and mechanical properties of a wear-resistant as-cast alloyed bainite ductile iron," Acta Metallurgica Sinica, vol. 27, no. 3, pp. 476-482, 2014.

[9] F. Pahlevani and M. Nili-Ahmadabadi, "Development of semisolid ductile cast iron," International Journal of Cast Metals Research, vol. 17, no. 3, pp. 157-161, 2004.

[10] M. Ramadan, N. El-Bagoury, N. Fathy, M. A. Waly, and A. A. Nofal, "Microstructure, fluidity, and mechanical properties of semi-solid processed ductile iron," Journal of Materials Science, vol. 46, no. 11, pp. 4013-4019, 2011.

[11] M. Ramadan, M. Takita, and H. Nomura, "Effect of semi-solid processing on solidification microstructure and mechanical properties of gray cast iron," Materials Science and Engineering A, vol. 417, no. 1-2, pp. 166-173, 2006.

[12] A. S. Roca, H. D. C. Fals, J. A. Pedron, and E. J. Zoqui, "Thixoformability of hypoeutectic gray cast iron," Journal of
Materials Processing Technology, vol. 212, no. 6, pp. 1225-1235, 2012.

[13] H. K. D. H. Bhadeshia, Worked Examples in the Geometry of Crystals, The Institute of Metals, London, UK, 2001.

[14] C. V. White, "Gray iron," in ASM Handbook, Properties and Selection: Irons, Steels and High-Performance Alloys, pp. 38-42, ASM International, Novelty, Ohio, USA, 1993. 

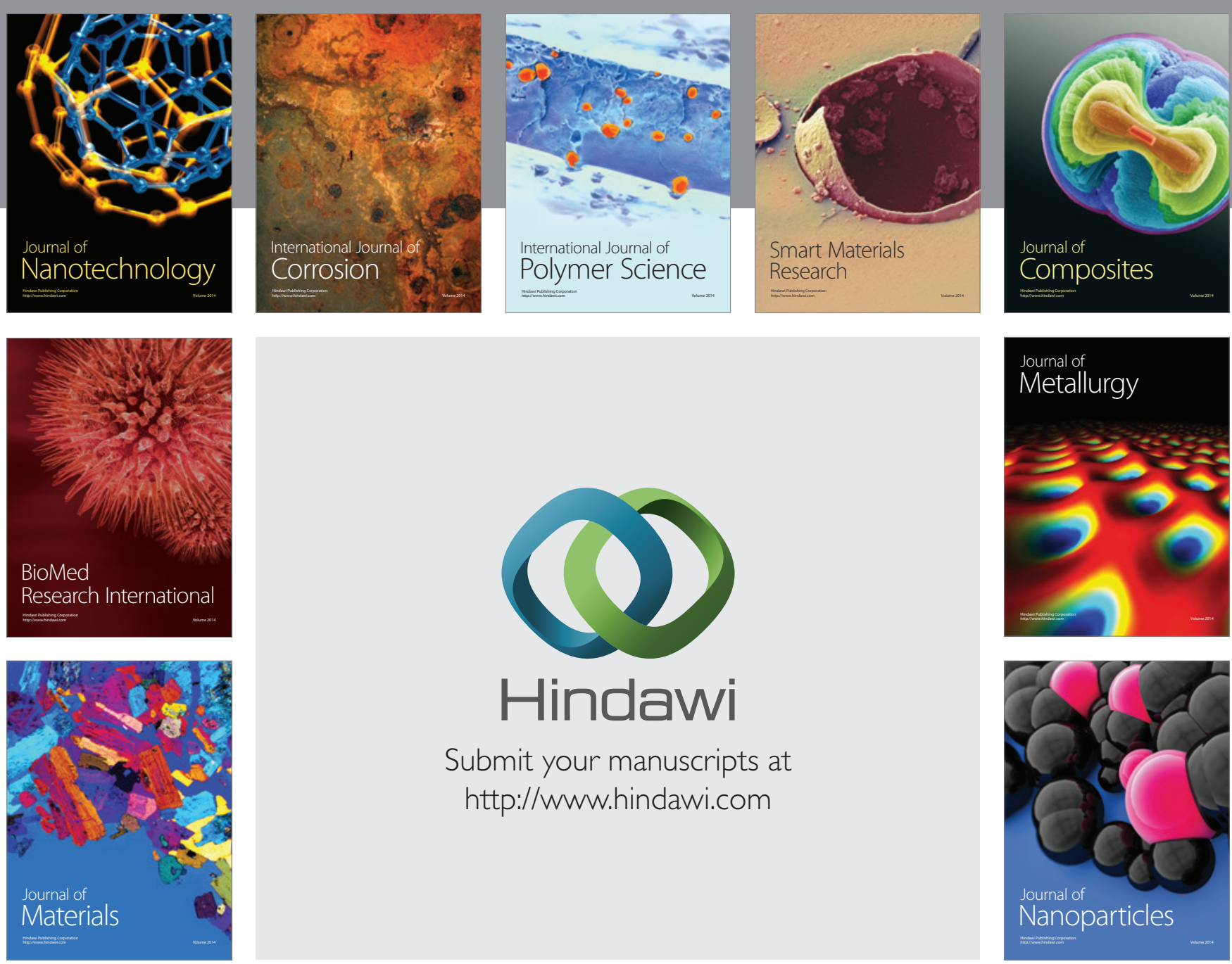

Submit your manuscripts at http://www.hindawi.com
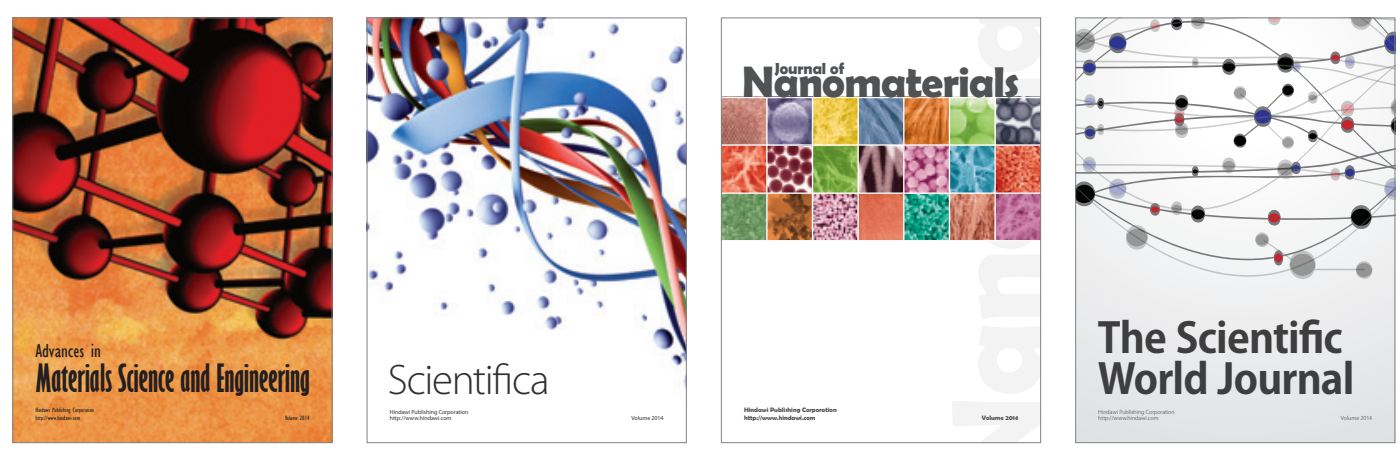

\section{The Scientific World Journal}
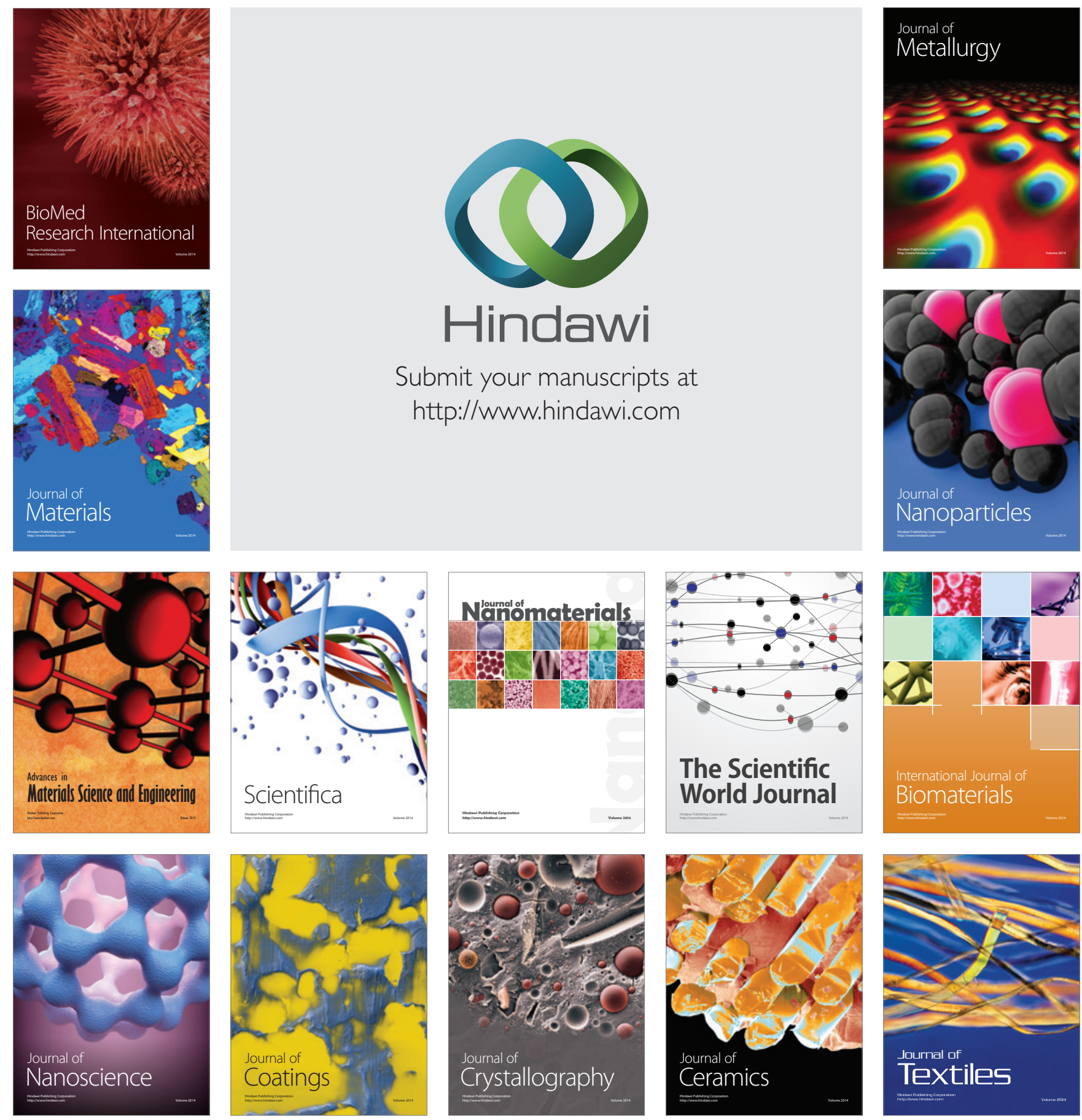